\title{
Analisa Perbandingan Least Significant Bit dan End Of File Untuk Steganografi Citra Digital Menggunakan Matlab
}

\author{
${ }^{1}$ Toni Sahata Pandapotan, ${ }^{2}$ Taronisokhi Zebua, M.Kom \\ ${ }^{I}$ Mahasiswa S1 Teknik Informatika Komputer STMIK Budi Darma Medan \\ ${ }^{2}$ Dosen Tetap STMIK Budi Darma Medan \\ Alamat Korespondensi : tonisahata2410@gmail.com
}

\begin{abstract}
ABSTRAKSI
Steganografi merupakan salah satu metode yang dapat digunakan untuk mengamankan pesan rahasia pada media lain seperti citra, audio, video maupun teks. Ada beberapa metode yang digunakan dalam steganografi antara lain metode least significant bit dan end of file.Masing-masing metode steganografi memiliki kelebihan dan kelemahan yang merupakan salah satu pertimbangan penting dalam pemilihan metode yang sangat cocok untuk digunakan. Pemanfaatan setiap metode dari steganografi dapat mempengaruhi size, resolusi maupun kualitas dari pesan maupun media yang digunakan. Pertimbangan terhadap perubahan size, resolusi maupun kualitas dari output yang dihasilkan merupakan salah satu elemen penting yang harus dipertimbangkan sebelum metode steganografi digunakan. Pemilihan metode yang terbaik dalam menyisipkan pesan teks ke dalam citra dapat diketahui dengan melakukan analisa serta perbandingan terhadap metode steganografi yang ingin digunakan berdasarkan parameter kualitas citra maupun besar ukuran file setelah dilakukan penyisipan. Kualitas citra pada metode least significant bit dapat diukur dengan melakukan perhitungan nilai Mean Square Error (MSE) dan Peak Signal to Noise Ratio (PSNR), sedangkan kualitas citra berdasarkan metode end of file tidak dapat dihitung dengan perhitungan MSE dan PSNR karena kualitas citra awal (cover) dan citra setelah disisipkan pesan tidak mengalami perubahan. Matlab digunakan dalam penelitian ini sebagai aplikasi untuk membantu proses implementasi dan pengujian.
\end{abstract}

Kata Kunci : Steganografi, Least Significant Bit, End of File, MSE, PSNR.

\section{PENDAHULUAN}

End of File merupakan metode penyisipan pesan diakhir file citra. Pesan yang disisipkan pada metode end of file jumlahnya tak terbatas, Akan tetapi efek sampingnya adalah hasil citra digital setelah dilakukan penyisipan pesan maka citra yang tampil memiliki hasil perbedaan dari citra semula. Hasil citra yang berbeda pasti akan menimbulkan kecurigaan bagi orang-orang yang mengetahuinya (Krisnawati, 2008). Saat ini pemanfaatan teknik steganografi untuk meningkatkan keamanan pesan rahasia telah banyak digunakan seiring dengan perkembangan teknologi informasi seperti metode LSB maupun EOF. Masalah yang selama ini terjadi pada saat memilih metode-metode penyembunyian pesan adalah tidak diperhitungkan terlebih dahulu seberapa efisienkah metode yang dipakai dalam menyisipkan pesan ke dalam citra digital, sehingga ouput citra digital selalu memiliki kekurangan dalam tingkat efisiensi kecepatan dan size dalam proses penyisipan pesan.

Penelitian ini bertujuan untuk menjelaskan proses penyembunyian pesan rahasia ke dalam citra digital berdasarkan metode End of File dan Metode Least Significant Bit kemudian melakukan perbandingan terhadap kualitas citra ouput dari masing-masing metode sehingga dapat diketahui metode yang paling efektif dan efesien dalam penyembunyian pesan rahasia terutama terhadap kualitas dan size citra output.

\section{BAHAN DAN METODE}

\section{Bahan}

Pelaksanaan penelitian ini tidak terlepas dari beberapa hal yang menjadi kebutuhan mendasar seperti bukubuku yang menjadi referensi metode end of file dan metode least significant bit serta citra yang dijadikan sebagai bahan uji coba dalam penelitian. Berdasarkan teori-teori yang didapatkan dari berbagai referensi yang digunakan maka dapat dijadikan sebagai landasan dalam melakukan analisa serta perbandingan untuk mencapai tujuan penelitian ini. 


\section{Metode}

\section{Steganografi}

Istilah steganografi berasal dari bahasa Yunani, yang berarti tulisan yang tertutup/tersamar (covered letter). Arti lain steganografi dapat dikatakan sebagai cara komunikasi yang menyembunyikan pesan. Data/pesan yang akan dikirim disembunyikan ke media lain. Format media yang bisa dipakai diantaranya adalah format image, format audio dan format lainnya. Bentuk data/pesan tidak berubah, hanya saja karena data/pesan tersebut dikirim dengan disembunyikan dalam media lain, maka yang terlihat adalah media yang dipakai untuk mengirimkan data/pesan tersebut (Krisnawati, 2008). Beberapa kriteria yang penting diperhatikan pada teknik steganografi adalah imperceptibility, fidelity serta recovery. Sedangkan tujuan utama dari teknik steganografi adalah injection, substitution, transform domain, spread spectrum, statiscal method, distortion dan cover generation (Lovebbi, Dodick Z. Sudirman, 2012).

\section{Metode Least Significant Bit}

Least Significant Bit merupakan algoritma terapan dari metode substitusi. Substitusi merupakan sebuah metode dimana data normal digantikan dengan data rahasia. Teknik ini tidak terlalu mengubah ukuran data asli, tetapi tergantung pada file media dan data yang akan disembunyikan. Setiap bit pesan menggantikan bit yang paling akhir dari data asli. Ukuran bayaknya pesan yang disembunyikan bergantung pada ukuran citra penampung. Misalkan citra 8-bit yang berukuran 256 x 256 pixel terdapat 65536 pixel, setiap pixel berukuran 1 byte. Setiap byte hanya bisa menyembunyikan satu bit di LSB-nya, maka ukuran data yang akan disembunyikan di dalam citra maksimum 65536/8 = 8192 byte, apabila pesan yang akan disisipkan melebihi ukuran citra penampung maka proses embeding pesan tidak akan dapat dilakukan. Adapun kelebihan dan kekurangan dari metode Least Significant Bit yaitu ukuran gambar yang telah disisipi karakter pesan tidak akan berubah. Sedangkan kekurangannya adalah jumlah karakter pesan/data yang akan disisipkan sangat terbatas, sehingga harus disesuaikan dengan ukuran citra.

\section{Metode End Of File}

Teknik ini bekerja dengan cara menambahkan data atau pesan rahasia pada akhir file. Teknik ini dapat digunakan untuk menambahkan data yang ukurannya sesuai dengan kebutuhan. Perhitungan kasar ukuran file yang telah disisipkan data yang sama dengan ukuran file sebelum disisipkan, data ditambah ukuran data rahasia yang telah diubah menjadi encoding file. Metode EOF merupakan sebuah metode yang diadaptasi dari metode penanda akhir file (end of file) yang digunakan oleh sistem operasi windows. Jika terdapat pada sistem operasi windows penanda EOF dalam sebuah file, maka sistem akan berhenti melakukan pembacaan pada file tersebut. Prinsip kerja EOF menggunakan karakter/simbol khusus yang diberikan pada setiap akhir file. Adapun kelebihan metode end of file yaitu memiliki kapasitas jumlah karakter pesan tidak terbatas pada saat disisipkan. Akan tetapi kekurangan metode ini yaitu hasil file citra digital akan semakin besar jika dibandingkan dengan gambar asli sebelum disisipkan pesan.

\section{Perhitungan Size Citra BMP}

Kedalaman bit merupakan faktor penting yang mempengaruhi kualitas gambar dan ukuran file. kedalaman bit mengacu pada jumlah informasi yang disimpan untuk setiap pixel dari suatu gambar . bit paling umum kedalaman untuk gambar 8-bit dan 24-bit. Kedalaman 8-bit dapat memuat gambar sebanyak 256 warna, namun kedalaman 24-bit dapat memuat gambar sebanyak 16.777.216 warna. Matematika perhitungan ukuran file (dalam bytes) dari suatu gambar dengan rumus berikut (Robert Reinhardt, Snow Dowd, 2009) :

$$
\text { Ukuran file }=\text { lebar (kolom) } \mathrm{x} \text { tinggi (baris) } \mathrm{x} \text { ( kedalaman bit) / } 8
$$

\section{MSE dan PSNR}

Peak Signal to Noise Ratio (PSNR) adalah perbandingan antara nilai maksimum dari sinyal yang diukur dengan besarnya derau yang berpengaruh pada sinyal tersebut. PSNR diukur dalam satuan desibel. Pada penelitian ini, PSNR digunakan untuk mengetahui perbandingan kualitas citra cover sebelum dan sesudah disisipkan pesan. Untuk menentukan PSNR, terlebih dahulu harus ditentukan MSE (Mean Square Error). MSE adalah nilai error kuadrat rata-rata antara citra cover dengan citra tersteganografi, secara matematis dapat dirumuskan seperti pada persamaan (2) berikut :

$$
\mathrm{MSE}=\frac{1}{\mathrm{MN}^{\mathrm{N}}} \sum_{\mathrm{y}=1}^{\mathrm{M}} \sum_{\mathrm{x}=1}^{\mathrm{N}}\left[\mathrm{I}(\mathrm{x}, \mathrm{y})-\mathrm{I}^{\prime}(\mathrm{x}, \mathrm{y})\right]^{2}
$$

Dimana :

MSE = Nilai MSE citra steganografi; $M=$ Panjang citra stego (dalam pixel)

$\mathrm{N}=$ Lebar citra stego $($ dalam pixel $) ; \mathrm{I}(\mathrm{x}, \mathrm{y})=$ nilai piksel dari citra cover

$\mathrm{I}^{\prime}(\mathrm{x}, \mathrm{y})=$ nilai piksel pada citra stego

Setelah diperoleh nilai MSE maka nilai PSNR dapat dihitung dari kuadrat nilai maksimum dibagi dengan MSE. Secara matematis, nilai PSNR dirumuskan seperti pada persamaan (3) : 
Dimana :

$$
\mathrm{PSNR}=\log _{10}\left(\frac{\mathrm{MAXi}^{2}}{\mathrm{MSE}}\right)
$$

MSE adalah Nilai MSE; MAXi adalah Nilai maksimum dari pixel citra

Semakin rendah nilai MSE maka akan semakin baik, dan semakin besar nilai PSNR maka semakin baik kualitas citra steganografi.

\section{HASIL DAN PEMBAHASAN}

Cara Kerja Metode LSB. Konsep kerja metode Least Significant Bit (LSB) dalam melakukan penyisipan pesan ke dalam media citra adalah melakukan modifikasi terhadap bit-bit setiap pixel citra yang menjadi cover (citra penampung pesan). Bit paling akhir (least) dari setiap pixel akan digantikan dengan bitbit dari pesan yang akan disembunyikan. Proses pengungkapan atau pengambilan pesan dari dalam citra penampung dilakukan dengan mengambil bit-bit pixel citra hasil yang berada pada posisi akhir, kemudian dikonversikan menjadi karakter. Proses utama dalam metode LSB adalah proses embedding dan proses ekstraction.

Proses Embedding Berdasarkan LSB. Proses embedding pesan pada cover yang dijadikan sebagai penampung yaitu dengan tahapan memilih citra cover, baca nilai desimal cover, konversi kedalam bilangan biner, kemudian masukkan pesan, setelah itu jumlah pesan yang dijadikan sebagai kunci digabungkan dengan pesan yang ingin disembunyikan, maka hasil gabungan pesan dan kunci menjadi pesan yang akan disisipkan ke dalam citra cover, setelah itu nilai pesan dikonversi ke dalam bilangan biner. Apabila jumlah biner pesan dapat ditampung semua pada citra cover berdasarkan kriteria perhitungan jumlah piksel dibagi dengan 8 bit, maka dapat dilakukan proses penukaran bit. Setelah disisipkan pesan pada cover, hasil dari nilai biner cover baru dikonversi kembali ke dalam bilangan desimal dan kemudian dipetakan menjadi citra baru atau stegoimage. Sebagai contoh proses penyisipan pesan bisa dilihat pada gambar 1 di bawah ini:

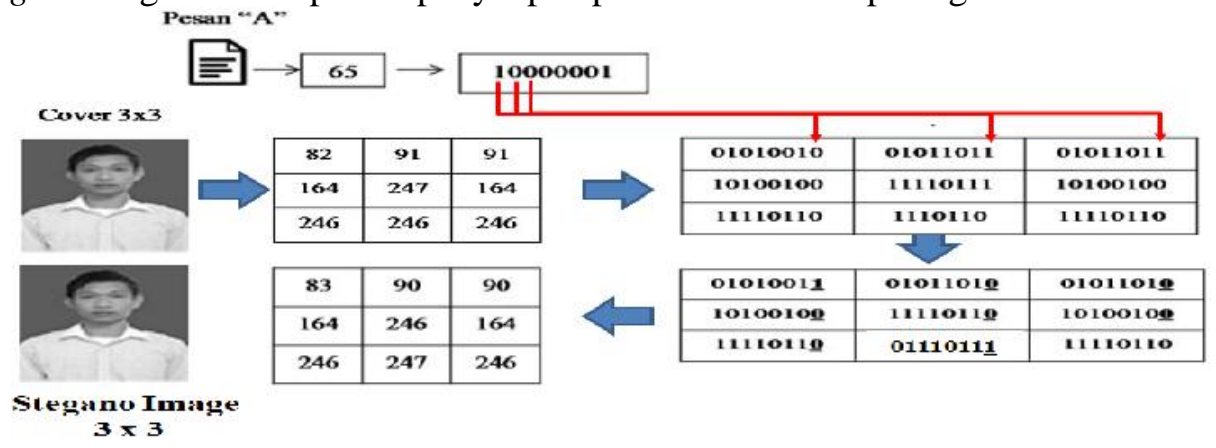

Gambar 1 : Penyisipan Pesan ke dalam Citra Berdasarkan Metode LSB

Berdasarkan gambar di atas, maka dapat dilihat bahwa terjadinya perubahan terhadap nilai-nilai desimal pixel citra hasil (stegano image) yang diakibatkan oleh modifikasi terhadap nilai-nilai bit akhir dari pixel citra cover. Perubahan tersebut secara penglihatan mata manusia tidak begitu terlihat secara signifikan, sehingga stegano image masih terlihat sama dengan citra cover.

Proses Extraction Pesan Berdasarkan Metode LSB. Adapun Proses extraction pesan dari hasil stegoimage, yaitu dengan tahapan masukkan stegoimage, setelah itu baca nilai piksel stegoimage dan konversi ke bilangan biner, kemudian ambil nilai kunci dari 8 bit LSB biner citra awal stegoimage dan dikonversi ke bilangan desimal, kemudian nilai kunci dikalikan dengan 8 bit untuk mengambil nilai bit pesan. Setelah itu ambil bit LSB dari setiap elemen piksel dimulai dari bit ke-9 hingga sejumlah perkalian kunci dengan 8 bit lalu ditambahkan dengan 8 bit kunci LSB, kemudian kelompokkan nilai bi-bit LSB menjadi 8 bit perkelompok, kemudian dikonversi kedalam bilangan desimal. Setelah didapatkan bilangan desimal dari biner pengelompokan, konversi ke karakter, karakter yang dihasilkan tersebutlah yang menjadi pesan yang telah disembunyikan sebelumnya.

Cara Kerja Metode EOF. Konsep kerja metode End of File (EOF) dalam menyembunyikan pesan ke dalam citra digital adalah melakukan penambahan pixel baru setelah data akhir pixel dari citra cover (citra asli). Jumlah pixel yang ditambahkan sama dengan jumlah karakter pesan yang ingin disembunyikan dengan tidak merubah ukuran lebar dari citra cover (yang berubah hanyalah ukuran height dari citra). Bila jumlah kolom tidak terpenuhi, maka akan dilakukan penambahan pixel sejumlah kolom yang masih kurang pada baris. Proses penambahan pixel inilah yang menyebabkan terjadinya perubahan ukuran tinggi dari citra hasil (stegano image). Proses pengungkapan (extraction) pesan dari dalam stegano image dilakukan dengan mengambil nilai-nilai pixel yang baru ditambahkan kemudian dikonversi menjadi karakter.

Proses Embedding Pesan Berdasarkan Metode EOF. Proses embedding (penyisipan) pesan dengan metode EOF yaitu dengan tahapan memilih citra digital untuk dijadikan sebagai cover, kemudian baca nilai desimal cover, setelah itu masukkan pesan yang akan disisipkan, setelah itu masukkan kunci sebanyak 2 
karakter, maka lanjutkan konversi nilai desimal pesan, setelah itu lakukan proses EOF dengan menempatkan nilai desimal kunci digabungkan dengan pesan, yang dimana kunci ditempatkan pada nilai awal dan nilai akhir pada citra cover. Nilai kunci dan pesan akan menjadi kolom baru pada piksel citra, kemudian setelah disisipkan maka akan didapatkan nilai desimal hasil penyisipan pesan. Selanjutnya tambahkan nilai baris kunci pada piksel kolom dan baris terakhir, maka tahapan selanjutnya yaitu petakan menjadi citra baru (stegoimage).

Sebagai contoh proses penyisipan pesan bisa dilihat pada gambar 2 di bawah ini:

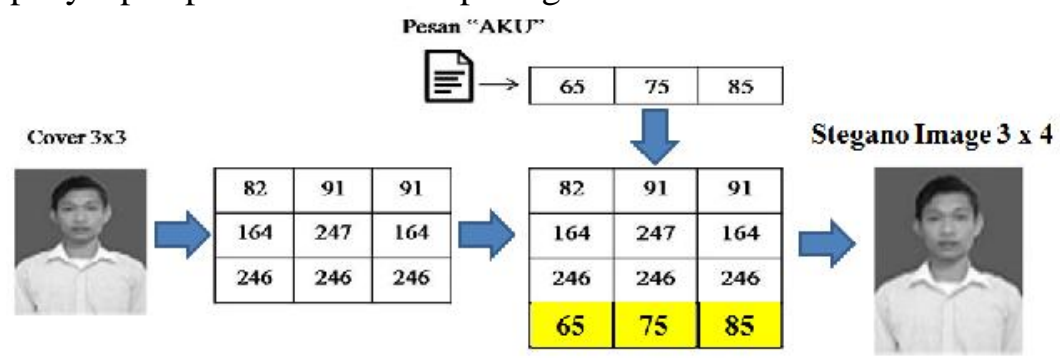

Gambar 2 : Penyisipan Pesan Ke Dalam Citra Berdasarkan EOF

Berdasarkan gambar 2 di atas, maka terlihat bahwa terjadinya perubahan ukuran tinggi dari citra hasil (stegano image) dari ukuran $3 \times 3$ menjadi $3 \times 4$.

Proses Extraction (Pengungkapan) Pesan Berdasarkan Metode EOF. Proses extraction pesan dari hasil stegoimage yaitu dengan tahapan memasukkan stegoimage, setelah itu baca nilai desimal piksel dari stegoimage, kemudian ambil nilai baris kunci dari kolom dan baris terakhir, setelah itu masukkan 2 karakter kunci, kemudian ambil nilai desimal pesan berdasarkan nilai desimal 2 karakter kunci, maka akan didapatkan nilai desimal pesan, kemudian nilai desimal dikonversi ke bentuk karakter, maka akan didapatkan hasil pesan yang disisipkan

Hasil Perbandingan. Perbandingan yang dilakukan meliputi aspek ukuran (size) dan kualitas citra. Hasil perbandingan ukuran (size) citra didapatkan berdasarkan formula pada persamaan (1). Berdasarkan persamaan (1), maka dapat diketahui ukuran (size) citra cover dan citra hasil (stegano image). Perbadingan kualitas citra dapat diketahui berdasarkan formula pada persamaan (2) dan persamaan (3), yaitu menghitung nilai PSNR dan nilai MSE citra hasil (stegano image) terhadap citra cover. Berdasarkan hasil perbandingan yang dilakukan, maka didapatkan bahwa kedua metode ini memiliki kelebihan dan kekurangan yang dapat dilihat pada tabel 1 di bawah ini :

Tabel 1 : Hasil Perbandingan Metode LSB dan EOF

\begin{tabular}{|l|l|}
\hline \multicolumn{1}{|c|}{ Metode LSB } & \multicolumn{1}{|c|}{ Metode EOF } \\
\hline 1. Ukuran file tetap & $\begin{array}{l}\text { 1. Ukuran file mengalami peberubah akibat } \\
\text { penambahan pixel }\end{array}$ \\
$\begin{array}{l}\text { 3. Jumlah piksel citra tetap } \\
\text { 4. Ukuran height stegano image sama dengan } \\
\text { ukuran heigh citra cover. }\end{array}$ & $\begin{array}{l}\text { 2. Jumlah pixel stegano image bertambah } \\
\text { 3ualitas citra digital tetap. } \\
\text { 4. Ukuran Height citra hasil (stegano image) } \\
\text { bertambah }\end{array}$ \\
\hline
\end{tabular}

Tabel 2 : Hasil Implementasi

\begin{tabular}{|c|c|c|c|c|c|c|c|c|c|}
\hline \multicolumn{5}{|c|}{ Metode LSB } & \multicolumn{5}{|c|}{ Metode EOF } \\
\hline \multirow[b]{2}{*}{ Gambar } & \multirow[b]{2}{*}{ Pesan } & \multicolumn{2}{|c|}{ Size of file } & \multirow{2}{*}{$\begin{array}{c}\text { Kualitas } \\
\text { citra } \\
\text { MSE/PSNR }\end{array}$} & \multirow[b]{2}{*}{ Gambar } & \multirow{2}{*}{ Pesan } & \multicolumn{2}{|c|}{ Size of file } & \multirow{2}{*}{$\begin{array}{l}\text { Kualitas citra } \\
\text { MSE/PSNR }\end{array}$} \\
\hline & & cover & stego & & & & cover & stego & \\
\hline
\end{tabular}




\section{KESIMPULAN}

Berdasarkan penelitian yang telah dilakukan, maka disimpulkan bahwa :

1. Proses penyisipan metode LSB dan EOF memiliki perbedaan, dimana dalam metode LSB penyisipan bit pesan menggantikan bit terakhir dari citra cover, sedangkan metode EOF penyisipan pesan ditempatkan pada piksel yang baru dari citra cover.

2. Keunggulan lebih banyak didapatkan pada metode LSB dibandingkan dengan metode EOF dikarenakan citra setelah disisipkan pesan hanya mengalami sedikit penurunan kualitas yang tidak begitu berpengaruh secara signifikan bila dilihat oleh mata manusia, sedangkan mettode EOF mengalami perubahan yang signifikan pada ukuran citra, sehingga untuk metode penyisipan pesan pada gambar lebih baik jika digunakan menggunakan metode LSB.

3. Adapaun hasil perbandingan citra berdasarkan output/tampilan citra setelah penyisipan pesan yaitu teknik yang lebih baik adalah metode LSB karena citra akhir tidak memperlihatkan perbedaan yang signifikan oleh penglihatan manusia bila dibandingkan dengan citra awalnya.

\section{DAFTAR PUSTAKA}

Abdul Kadir, Adhi Susanto, 2013. Teori dan Aplikasi Pengolahan Citra, Andi, Yogyakarta.

Desi Lilyani, 2014. Implementasi Steganografi Pada Citra Digital Dengan Menggunakan Metode Dynamic Cell Spreading, Pelita Informatika Budi Darma, 1-8.

Irawan Afrianto, Taryana Suryana, Sufa'atin, 2015. Pengukuran dan Evaluasi Keamanan Informasi Menggunakan Indeks KAMI - SNI, ULTIMA InfoSys, 43-49.

Jogiyanto, 2005. Analisis dan Desain Sistem Informasi Pendekatan Terstruktur Teori dan Praktik Aplikasi Bisnis, Andi, Yogyakarta.

Jaka Putra, 2014. Implementasi Histogram Equalization Untuk Perbaikan Noise Pada Citra Digital, Pelita Informatika Budi Darma, 56-60.

Krisnawati, 2008. Metode Least Significant Bit (LSB) Dan End Of File (EOF) Untuk Menyisipkan Teks Ke Dalam Citra Grayscale, Seminar Nasional Informatika, 39-44.

Lovebbi, Dodick Z. Sudirman. Rancang Bangun Aplikasi Steganografi dengan Metode Least Significant Bit di Audio pada Sistem Operasi Android, 2012, Ultimatics, 7-16.

Makinuddin, Tri Hadiyanto Sasongko, 2006. Analisis Sosial Bersaksi dalam Advokasi Irigasi, Yayasan Akatiga, Bandung.

Muhtadan, Djiwo Harsono, 2008. Pengembangan Aplikasi untuk Perbaikan Citra Digital Film Radiografi, Seminar Nasional IV SDM Teknologi Nuklir, Yogyakarta, 467-478.

Murinto, Willy Permana Putra, Sri Handayaningsih, 2008. Analisis Perbandingan Histogram Equalization dan Model Logarithmic Image Processing (LIP) untuk Image Enhancement, Jurnal Informatika, 200208.

Nazaruddin Ahmad, Arifyanto Hadinegoro, 2012. Metode Histogram Equalization untuk Perbaikan Citra Digital, Seminar Nasional Teknologi Informasi dan Komunikasi Terapan, 439-445.

RD Kusumanto, Alan Novi Tompunu, 2011. Pengolahan Citra Digital untuk Mendeteksi Obyek Mengunakan Pengolahan Warna Model Normalisasi RGB, Seminar Nasional Teknologi Informasi dan Komunikasi Terapan, 1-7.

Robert Reinhardt, Snow Dowd, 2009. Adobe Flash CS4 Professional Bible. Indianapolis: Wiley Publishing.

Wahana Komputer, 2013. Ragam Aplikasi Pengolahan Image dengan MATLAB. Jakarta: PT Elex Media Komputindo.

Wasino, Tri Puji Rahayu, Setiawan, 2012. Implementasi Steganografi Teknik End Of File dengan Enkripsi Rijndael, Seminar Nasional Teknologi Informatika dan Komunikasi, 150-157.

Yayuk Anggraini, Dolly Virgian Shaka Yudha Sakti, 2014. Penerapan Steganografi Metode End Of File (Eof) Dan Enkripsi Metode Data Encryption Standard (Des) Pada Aplikasi Pengamanan Data Gambar Berbasis Java Programming, Konferensi Nasional Sistem Informasi STMIK Dipanegara Makassar, 1743-1753. 